Al Maal : Journal of Islamic Economics and Banking

http://jurnal.umt.ac.id/index.php/jieb

E-ISSN : $2580-3816$

Vol : 2 No. 1 Bulan Juli Tahun 2020

Hlm : $25-37$

DOI $\quad$ : $\quad 10.31000 /$ almaal.v2i1.2718

\title{
Pengaruh Karakteristik Dewan Pengawas Syari'ah dan Ukuran Dewan Komisaris terhadap Pengungkapan Islamic Social Reporting
}

\section{Firman Setiawan ${ }^{1 *}$}

${ }^{1}$ Program Studi Ekonomi Syari'ah, Fakultas Keislaman, Universitas Trunojoyo Madura, Jawa Timur, Indonesia

*firman.setiawan@trunojoyo.ac.id

\section{ABSTRACT}

This study aims to determine the effect of Shari'ah Supervisory Board Characteristics (DPS Size, DPS Education Level, and DPS Expertise) and Board of Commissioners Size on Islamic Social Reporting (ISR) Disclosure at Shari'ah Commercial Banks in 2018. Population in this study is a Sharia Commercial Bank in Indonesia in 2018. Data is obtained from the bank's annual report. The data is presented and analyzed quantitatively using multiple linear regression. Based on the analysis conducted, it is known that the Shari'ah Supervisory Board Size, Shari'ah Supervisory Board Education Level and the Shari'ah Supervisory Board Expertise partially have no significant effect on Islamic Social Reporting (ISR) Disclosure, while the Size of the Board of Commissioners has a significant effect on Islamic Social Reporting (ISR) Disclosures. Simultaneously, DPS Characteristics and Board of Commissioners Size significantly influence Islamic Social Reporting (ISR) Disclosure.

Keywords: Sharia Supervisory Board; Board of Commissioners; Islamic Social Reporting.

\section{ABSTRAK}

Penelitian ini bertujuan untuk mengetahui apakah Karakteristik Dewan Pengawas syari'ah (Ukuran DPS, Tingkat Pendidikan DPS, dan Keahlian DPS) dan Ukuran Dewan Komisaris berpengaruh secara positif terhadap Pengungkapan Islamic Social Reporting (ISR) pada Bank Umum Syari'ah di tahun 2018. Populasi dalam penelitian ini adalah Bank Umum Syari'ah yang ada di Indonesia pada tahun 2018. Data diperoleh melalui laporan tahunan bank. Data tersebut kemudian disajikan dan dianalisis secara kuantitatif dengan menggunakan regresi linier berganda. Berdasarkan analisis yang dilakukan, diketahui bahwa Ukuran Dewan Pengawas Syari'ah, Tingkat Pendidikan Dewan Pengawas Syari'ah dan Keahlian Dewan Pengawas Syari'ah secara parsial tidak berpengaruh signfikan terhadap Pengungkapan Islamic Social Reporting (ISR), sedangkan Ukuran Dewan Komisaris berpengaruh secara signifikan terhadap Pengungkapan Pengungkapan Islamic Social Reporting (ISR). Adapun secara simultan, Karakteristik DPS dan Ukuran Dewan Komisaris berpengaruh secara signifikan terhadap Pengungkapan Islamic Social Reporting (ISR).

Kata kunci : Dewan Pengawas Syari'ah; Dewan Komisaris; Islamic Social Reporting. 


\section{Pendahuluan}

Saat ini, perusahaan dihadapkan pada sebuah keharusan secara sosial agar seluruh sistem yang dijalankan tidak hanya berpegang pada optimalisasi keuangan, tetapi juga harus memperhatikan aspek sosial dan lingkungan. Konsep ini kemudian dikenal dengan konsep Triple Bottom Line (TBL). Dengan konsep TBL, perusahaan tidak hanya berpacu dalam optimalisasi keuntungan, tetapi juga berusaha untuk memenuhi tanggung jawab secara sosial yang pada umumnya disebut sebagai Corporate Sosial Responsibility.

Perusahaan tidak hanya bertanggung jawab secara keuangan dan legal kepada investor dan pemegang saham, tetapi juga kepada pihak-pihak terkait yang memiliki kepentingan, meliputi karyawan perusahaan sebagai pihak internal dan masyarakat secara umum sebagai pihak eksternal. (Busyra Azheri, 2011)

Corporate Social Responsibility (Tanggung Jawab Sosial Perusahaan) adalah wacana yang semakin hari semakin ramai diperbincangkan dalam dunia bisnis, baik di dunia maupun di Indonesia. Hal ini disebabkan oleh semakin meningkatnya kepedulian perusahaan terhadap praktek CSR dalam bisnis, baik sebagai beban moral dan sosial yang harus dilaksanakan maupun untuk meningkatkan citra perusahaan, baik bagi investor maupun bagi masyarakat secara umum.(Fauziah \& J, 2013) Penerapan indeks penilaian pengungkapan dan pelaporan CSR pada saham-saham yang masuk kategori perusahaan yang telah mempraktikkan CSR juga sudah mulai terlihat di pasar modal. Sebagai contoh, Dow Jones Sustainability Indeks (DJSI) yang ada di New York Stock Exchange, Socially Responsible Investment (SRI) Indeks yang ada di London Stock Exchange dan FTSE4Good yang ada di Financial Times Stock Exchange (FTSE). Bahkan tidak hanya di Amerika dan Eropa, inisiatif ini juga sudah mulai diikuti oleh otoritas bursa saham yang ada di Asia, misalnya Hanseng Stock Exchange dan Singapore Stock Exchange. (Fitria \& Hartanti, 2010)

Tren perkembangan wacana dan implementasi Corporate Social Responsibility (CSR) ini tidak hanya terjadi dalam ekonomi konvensional, melainkan juga terjadi di ekonomi Islam. Bahkan konsep dan implementasi CSR pada perusahaan-perusahaan yang menerapkan nilai-nilai syari'ah dalam kegiatan bisnisnya, memiliki dimensi yang lebih luas, baik dari sisi pelaksanaannya maupun pelaporannya. Hal ini karena perusahaanperusahaan tersebut selain harus melaksanakan tanggung jawab sebagaimana dalam konsep CSR, juga harus konsisten dengan penerapan prinsip-prinsip syari'ah Islam dalam semua kegiatan bisnis dan operasionalnya. (Marharani \& Yulianto, 2016)

Secara prinsip, konsep CSR ini sejalan dengan syari'ah islam, bahkan bisa dikatakan bahwa syari'ah mengilhami pengembangan konsep CSR sehingga menjadi lebih relevan untuk diterapkan saat ini. Karena itu konsep CSR yang kemudian dipadukan dan dikembangkan dengan konsep syari'ah ini bisa menjadi formulasi baru yang lebih baik dari konsep sebelumnya. (Astuti, t.t.)

Penerapan CSR pada perusahaan-perusahaan yang menjalankan kegiatan bisnisnya berdasarkan prinsip syari'at Islam, khususnya di perbankan syari'ah, adalah sangat relevan karena beberapa faktor, yaitu prinsip syari'ah yang dijadikan sebagai landasan dalam kegiatan dan operasional perbankan syari'ah memang menuntut mereka untuk menjalankan kegiatan bisnis dan operasionalnya dengan berlandaskan akhlak, etika dan moral, terlebih ketika berkaitan dengan tanggung jawab sosial; jika melaksanakan tanggung jawab sosial berarti melaksanakan perintah Allah, maka CSR merupakan wujud dari ketaatan; serta mewujudkan kemaslahatan dan kesejahteraan, dan menghindari 
kerusakan dan kemiskinan sebagai prinsip dan kepentingan umum. (Fitria \& Hartanti, 2010)

Seiring dengan meningkatnya kebutuhan terhadap pengungkapan dan pelaporan tanggung jawab sosial di perusahaan-perusahaan yang kegiatan bisnisnya dijalankan berdasarkan prinsip syari'ah, termasuk di perbankan syari'ah, maka ada sebuah konsep yang tepat untuk menilai pengungkapan tanggung jawab sosial tersebut, yakni Islamic Social Reporting Indeks (indeks ISR). Indeks ISR ini merupakan kompilasi dari indikator dan sub indikator CSR yang dirumuskan oleh Accounting and Auditing Organization for Islamic Finansial Institutions (AAOIFI) yang kemudian dimodifikasi dan dikembangkan lebih lanjut oleh para peneliti sehingga menjadi formula indeks CSR yang harus diungkapkan oleh suatu entitas Islam. Karena itulah, Indeks ISR ini kemudian dianggap lebih baik dan lebih tepat untuk dijadikan sebagai instrumen dalam mengukur dan menilai pengungkapan dan pelaporan Coporate Social Responsibility yang sesuai dengan syari'at Islam. (Sunarsih \& Ferdiansyah, 2016; Fitria \& Hartanti, 2010)

Ada tanggung jawab bagi perusahaan-perusahaan yang menjalankan bisnisnya sesuai dengan prinsip syari'ah dan perusahaan-perusahaan yang ingin masuk di bursa saham syari'ah untuk memasukkan dimensi religius dalam pengungkapan laporan keuangannya. Hak ini dimaksudkan agar keinginan dan kebutuhan dari pemangku kepentingan dapat terpenuhi. (Sunarsih \& Ferdiansyah, 2016; Othman \& Thani, 2010)

Namun demikian, perusahaan-perusahaan yang secara konsisten memasukkan dimensi religius ini dalam laporan keuangannya masih terbatas. (Othman \& Thani, 2010) Perkembangan indeks ISR di Indonesia juga bisa dibilang masih tertinggal jika dibandingkan dengan negara-negara Islam lainnya. Selain karena pengungkapan ISR pada laporan-laporan perusahaan bersifat sukarela (voluntary), hal ini bisa saja disebabkan oleh minimnya pengawasan dan arahan dari Dewan Pengawas Syari'ah serta Dewan Direksi. (Khasanah \& Yulianto, 2015)

Berdasarkan beberapa penelitian yang telah dilakukan sebelumnya, ada beberapa hal yang kemudian berpengaruh terhadap pengungkapan Islamic Social Reporting (ISR) ini, seperti penelitian yang dilakukan oleh Ramadhani, dkk. bahwa Ukuran Perusahaan, Profitabilitas, Leverage dan Ukuran Dewan Pengawas Syariah berpengaruh secara positif terhadap Pengungkapan Islamic Social Reporting (ISR). Begitu juga penelitian yang dilakukan oleh Agustomi bahwa Ukuran Perusahaan, Ukuran Dewan Komisaris, Ukuran Dewan Pengawas Syari'ah, cross-directorship dan liputan media berpengaruh terhadap Islamic Social Reporting (ISR).

Oleh karena itu, penulis kemudian ingin mencoba untuk melakukan kajian tentang apakah Karakteristik Dewan Pengawas Syari'ah dan Ukuran Dewan Komisaris juga berpengaruh secara positif terhadap Islamic Social Reporting (ISR). Studi ini dilakukan pada Bank Umum Syari'ah di Indonesia dengan mengacu pada laporan tahun 2018.

\section{KAJIAN LITERATUR Krakteristik Dewan Pengawas Syari'ah}

DPS adalah suatu badan yang bertugas memberikan nasihat dan arahan kepada dewan direksi, serta melakukan pengawasan untuk memastikan bahwa produk dan operasional di lembaga keuangan syari'ah sesuai dengan prinsip syari'ah, khususnya fatwa Dewan Syari'ah Nasional. DPS diangkat dan diberhentikan di lembaga keuangan 
syari'ah melalui RUPS setelah mendapat rekomendasi dari DSN. (Eksandy, 2018; Agustomi, 2019)

Anggota Dewan Pengawas Syariah dianggap telah memenuhi persyaratan kompetensi apabila memiliki pengetahuan dan keahlian di bidang fiqh muamalah dan keuangan syari'ah. (Agustomi, 2019; Ramadhani dkk., 2016)

Karakteristik Dewan Pengawas Syari'ah yang dimaksudkan dalam penelitian ini mencakup tiga hal, yaitu :

1. Ukuran Dewan Pengawas Syari'ah

Ukuran dewan pengawas syariah adalah jumlah anggota (ketua dan anggota) DPS dalam sebuah perusahaan. Jumlah tersebut adalah sebagaimana yang tercantum pada laporan tahunan perusahaan. (Khoirudin, 2013). Jika ukuran Dewan pengawas syariah besar, yakni jumlah anggota DPS banyak, maka fungsi pengawasan untuk memastikan kepatuhan bank syariah terhadap hukum dan prinsip Islam akan berjalan secara optimal. Selain itu diharapkan juga bahwa mereka akan berperan dalam peningkatan pengungkapan Islamic Social Reporting (ISR) bank syariah. (Ramadhani dkk., 2016). Menurut Khoiruddin (2013), sebagaimana dikutip oleh Ramadhani, et. al., ukuran (jumlah anggota) DPS dapat mendorong pengungkapan ISR sehingga berimplikasi pada peningkatan level pengungkapannya. Maka semakin besar jumlah anggota dewan pengawas syariah, pengungkapan Islamic Social Reporting (ISR) juga akan semakin meningkat. (Ramadhani dkk., 2016).

Berdasarkan Peraturan Bank Indonesia No.11/33/PBI/2009 tentang pelaksanaan good corporate governance bagi bank umum syariah dan unit usaha syariah, DPS memiliki tugas dan wewenang untuk memberikan saran dan nasihat kepada direksi serta mengawasi kegiatan bank, baik kegiatan bisnis maupun kegiatan operasional, agar sesuai dengan prinsip syariah. Anggota Dewan Pengawas Syari'ah minimal berjumlah dua orang. Hal ini berdasarkan ketentuan Good Corporate Governance (GCG) sebagaimana yang tercantum dalam UU No. 40 tahun 2007 tentang perseroan terbatas. (Agustomi, 2019)

2. Tingkat Pendidikan Dewan Pengawas Syari'ah

Dewan Pengawas Syari'ah dengan tingkat pendidikan yang tinggi memiliki kemampuan analisis yang lebih besar dan profesional, dapat memberikan keputusan yang efektif, serta dapat memilih dan menetapkan apakah suatu peraturan dapat dilakukan sesuai prinsip syari'ah atau tidak. Dengan demikian, Dewan Pengawas Syari'ah dengan tingkat pendidikan yang tinggi dapat meningkatkan efektivitas organisasi. (Muti'ah Khoirunnisa, 2019)

3. Keahlian dewan Pengawas Syari'ah

Keahlian dewan pengawas syariah merupakan latar belakang keilmuan/keahlian yang dimiliki oleh Dewan Pengawas Syari'ah di bidang keuangan/perbankan syari'ah dan fiqh Mu'amalah.(Fitriana dkk., 2019) Keahlian DPS diketahui melalui riwayat pendidikan yang dijalani oleh anggota DPS, baik pendidikan formal maupun non-formal. 


\section{Ukuran Dewan Komisaris}

Ukuran Dewan Komisaris merupakan jumlah anggota Dewan Komisaris dalam suatu perusahaan, yang dinilai/diketahui dengan cara menghitung jumlah dewan komisaris yang tercantum dalam laporan tahunan perusahaan. Dewan Komisaris bertugas untuk melakukan pengawasan dan memastikan bahwa perusahaan melaksanakan tanggung jawab sosial. (Agustomi, 2019)

\section{Islamic Social Reporting (ISR)}

Islamic Social Reporting atau ISR adalah suatu standar pelaporan kinerja dan tanggung jawab sosial perusahaan yang berbasis syariah. Ada berbagai dimensi yang terkandung dalam ISR ini yang mana hal itu merupakan gambaran dari konsep dan prinsip syariah yang diterapkan oleh perusahaan, yakni antara lain dimensi moral, spiritual, dan material. Jadi, Islamic Social Reporting adalah pengungkapan tanggung jawab sosial perusahaan yang didasarkan pada prinsip-prinsip syari'at Islam. (Ahzar, 2013)

Nilai pada item-item CSR islami atau indeks ISR ini didapat melalui metode analisis isi. Metode analisis isi dilakukan pada laporan perusahaan, baik laporan tahunan maupun yang lainnya. (Astuti, t.t.)

\section{Hipotesis Dan Kerangka Berpikir}

Berdasarkan kajian yang dilakukan oleh penulis, maka rumusan hipotesis dalam penelitian ini adalah sebagai berikut :

1. Karakteristik Dewan Pengawas Syari'ah dan Ukuran Dewan Komisaris secara bersama-sama berpengaruh positif terhadap pengungkapan Islamic Social Reporting. (H1)

2. Ukuran Dewan Pengawas Syari'ah berpengaruh secara positif terhadap pengungkapan Islamic Social Report. (H2)

3. Tingkat Pendidikan Dewan Pengawas Syari'ah berpengaruh secara positif terhadap pengungkapan Islamic Social Report. (H3)

4. Keahlian Dewan Pengawas Syari'ah berpengaruh secara positif terhadap pengungkapan Islamic Social Report. (H4)

5. Ukuran Dewan Komisaris berpengaruh secara positif terhadap pengungkapan Islamic Social Report. (H5)

Adapun kerangka berpikir dalam penelitian ini adalah sebagai berikut :

Gambar 1. Kerangka Berpikir Penelitian

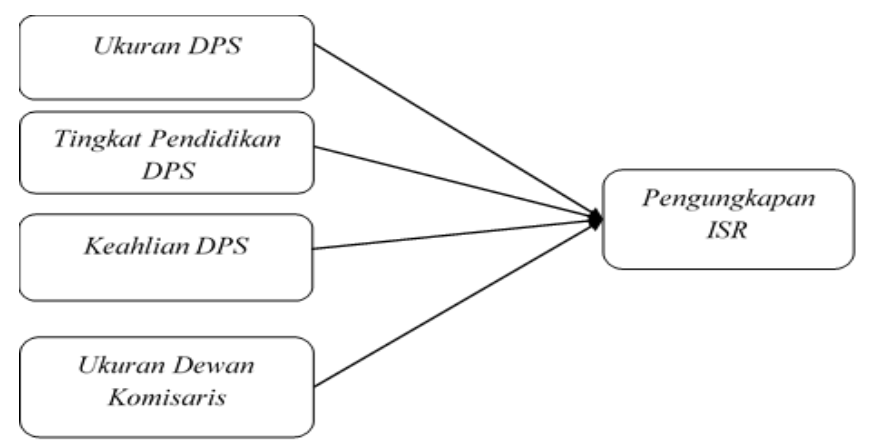




\section{Metode Penelitian}

Jenis penelitian yang digunakan dalam penelitian ini adalah penelitian dengan pendekatan kuantitatif deskriptif. Penelitian ini dilakukan dengan memecahkan masalah menggunakan angka-angka berupa laporan keuangan perusahaan. Perusahaan yang dimaksud adalah Bank Umum Syari'ah di Indonesia dengan laporan Keuangan tahun 2018.

Variabel bebas (independen variable) dalam penelitian ini adalah Ukuran Dewan Pengawas Syari'ah, Tingkat Pendidikan Dewan Pengawas Syari'ah, Keahlian Dewan Pengawas Syari'ah, dan Ukuran Dewan Komisaris; sedangkan variabel terikat (dependen variabel) dalam penelitian ini adalah Pengungkapan Islamic Social Report (ISR).

Ukuran Dewan Pengawas Syari'ah adalah jumlah DPS yang ada. Sehingga ukuran DPS diperoleh dengan rumus :

$$
\text { UDPS = Jumlah DPS }
$$

Tingkat Pendidikan DPS diukur dengan proporsi anggota DPS yang memiliki gelar S3. Tingkat Pendidikan DPS diperoleh dengar rumus :

$$
\text { TPDPS }=\frac{\text { Jumlah DPS dengan gelar S3 }}{\text { Total DPS }} \times 100 \%
$$

Keahlian Dewan Pengawas Syari'ah dalam penelitian ini dihitung berdasarkan proporsi anggota dewan pengawas syari'ah yang memiliki pengetahuan di bidang keuangan/perbankan syari'ah dan fiqh mu'amalah. Rumus penghitungannya adalah sebagai berikut :

$$
\text { KDPS }=\frac{\text { Jmlh DPS yang memiliki keahlian dan fiqh mu'amalah }}{\text { Total DPS }} \times 100 \%
$$

Ukuran Dewan Komisaris dihitung berdasarkan jumlah anggota dewa komisaris dalam perusahaan tersebut. Sehingga menghitung ukuran dewan komisaris adalah sebagai berikut :

$$
\text { UDK = Jumlah Dewan Komisaris. }
$$

Sedangkan untuk penilaian ISR dalam penelitian ini, masing-masing item akan diberikan angka ordinal untuk menunjukkan item yang ada (diungkapkan) dan tidak ada dalam laporan perusahaan. Penilaian item-item tersebut bukan merupakan nilai pembobotan, artinya nilai tidak didasarkan pada seberapa banyak dan seberapa baik item tersebut diungkapkan, namun hanya berdasarkan pada tersedia tidaknya informasi tersebut di dalam laporan perusahaan. Setiap item akan diberi nilai 1 jika diungkapkan dalam laporan perusahaan, dan akan diberi nilai 0 jika sebaliknya. Nilai dari masingmasing item tersebut kemudian dijumlahkan dan dibagi dengan total item. Setelah memberikan nilai (scoring) pada indeks ISR, maka kemudian menentukan besarnya disclosure level dengan menggunakan rumus berikut:

$$
\text { Disclosure level }=\frac{\text { Jumlah Skor Disclosure yang Dipenuhi }}{\text { Jumlah Skor Maksimum }}
$$


Berikut adalah tabel pengungkapan Islamic Social Report (ISR), meliputi indikator dan sub indikator.

Tabel 1. Pengungkapan Islamic Social Report (ISR)

\begin{tabular}{|c|c|}
\hline Indikator 1 & Pendanaan dan investasi \\
\hline 1 & Kegiatan yang mengandung Riba \\
\hline 2 & Kegiatan yang mengandung ketidakjelasan (gharar) \\
\hline 3 & Zakat (jumlahnya dan penerima zakatnya) \\
\hline 4 & $\begin{array}{l}\text { Kebijakan atas pembayaran tertunda dan penghapusan piutang tak } \\
\text { tertagih }\end{array}$ \\
\hline 5 & Kegiatan investasi (secara umum) \\
\hline 6 & Proyek pembiayaan (secara umum) \\
\hline Indikator 2 & Produk dan Jasa \\
\hline 7 & Persetujuan Dewan pengawas Syariah untuk suatu produk baru \\
\hline 8 & Definisi setiap produk \\
\hline 9 & Pelayanan atas keluhan konsumen \\
\hline Indikator 3 & Karyawan \\
\hline 10 & Jam kerja karyawan \\
\hline 11 & Hari libur \\
\hline 12 & Tunjangan karyawan \\
\hline 13 & Renumerasi karyawan \\
\hline 14 & $\begin{array}{l}\text { Pendidikan dan pelatihan karyawan (Pengembangan Sumber Daya } \\
\text { manusia) }\end{array}$ \\
\hline 15 & Kesetaraan hak antara pria dan wanita \\
\hline 16 & Kesehatan dan keselamatan karyawan \\
\hline 17 & Keterlibatan karyawan \\
\hline 18 & Lingkungan kerja \\
\hline 19 & $\begin{array}{l}\text { Karyawan dari kelompok khusus (misalnya cacat fisik atau mantan } \\
\text { pengguna narkoba) }\end{array}$ \\
\hline 20 & Tempat beribadah yang memadai bagi karyawan \\
\hline Indikator 4 & Masyarakat \\
\hline 21 & Pemberian donasi (sadaqah) \\
\hline 22 & Wakaf \\
\hline 23 & Pinjaman untuk kebaikan (Qardh Hasan) \\
\hline 24 & Sukarelawan dari kalangan karyawan \\
\hline 25 & Pemberian beasiswa sekolah \\
\hline 26 & Pemberdayaan kerja para lulusan sekolah/kuliah \\
\hline 27 & Pengembangan generasi muda \\
\hline 28 & Peningkatan kualitas hidup masyarakat \\
\hline 29 & Kepedulian terhadap anak-anak \\
\hline 30 & Menyokong kegiatan sosial kemasyarakatan/kesehatan/olahraga \\
\hline Indikator 5 & Lingkungan \\
\hline 31 & Konservasi lingkungan hidup \\
\hline 32 & Tidak membuat polusi lingkungan hidup \\
\hline 33 & Pendidikan mengenai lingkungan hidup \\
\hline 34 & Penghargaan/sertifikasi lingkungan hidup \\
\hline 35 & Sistem manajemen lingkungan \\
\hline
\end{tabular}




\begin{tabular}{ll}
\hline Indikator 6 & Tata Kelola Perusahaan \\
\hline 36 & Status kepatuhan terhadap Syariah \\
37 & Rincian nama direksi/ manajemen \\
38 & Profil jajaran direksi/ manajemen \\
39 & Rincian tanggung jawab manajemen \\
40 & Pernyataan mengenai remunerasi manajemen \\
41 & Jumlah pelaksanaan rapat manajemen \\
42 & Rincian nama dewan pengawas Syariah \\
43 & Profil dewan pengawas Syariah \\
46 & Rincian tanggung jawab dewan pengawas Syariah \\
47 & Pernyataan mengenai remunerasi dewan pengawas Syariah \\
48 & Jumlah remunerasi rapat dewan pengawas Syariah \\
49 & Struktur kepemilikan saham \\
50 & Kebijakan anti korupsi \\
\hline & Sumber : Fauziah \& J, 2013; Othman \& Thani, 2010; Sofyani dkk., 2012
\end{tabular}

Data yang digunakan dalam penelitian ini diperoleh melalui laporan tahunan Bank Umum Syari'ah di Indonesia pada tahun 2018.

Dalam proses analisis data, ada beberapa pengujian yang dilakukan, yaitu uji asumsi klasik, meliputi uji normalitas, multikolinieritas, dan autokorelasi; uji regresi linier berganda, hipotesis, yakni uji t dan uji F, serta uji Koefisien Determinasi.

\section{HaSil dan Pembahasan \\ Uji Asumsi Klasik}

\section{Uji Normalitas}

Tabel 2. Hasil Uji Normalitas

\begin{tabular}{lll}
\hline \multicolumn{1}{c}{$N$} & \multicolumn{1}{c}{12} \\
\hline Normal Parametersa,b & Mean &, 0000000 \\
& Std. Deviation &, 06773765 \\
Most Extreme Differences & Absolute &, 158 \\
& Positive &, 158 \\
& Negative &,- 112 \\
Test Statistic & &, 158 \\
Asymp. Sig. (2-tailed) & & $, 200 c, d$ \\
\hline
\end{tabular}

Sumber: Pengolahan Data di IBM SPSS Statistics 24

Berdasarkan tabel di atas, diketahui bahwa nilai Asymp. Sig adalah lebih besar dari 0,05, yakni 0,200 $(0,200>0,05)$. Dengan demikian dapat disimpulkan bahwa data berdistribusi normal. 
Pengaruh Karakteristik Dewan Pengawas Syari'ah dan Ukuran Dewan Komisaris terhadap Pengungkapan Islamic Social Reporting

\section{Uji Multikolinieritas}

Tabel 3. Hasil Uji Multikolinieritas

\begin{tabular}{|c|c|c|c|c|c|c|c|c|}
\hline \multicolumn{9}{|c|}{ Coefficientsa } \\
\hline & & \multicolumn{2}{|c|}{$\begin{array}{l}\text { Unstandardized } \\
\text { Coefficients }\end{array}$} & \multirow{2}{*}{$\begin{array}{l}\text { Standardized } \\
\text { Coefficients } \\
\text { Beta }\end{array}$} & \multirow[b]{2}{*}{$t$} & \multirow[b]{2}{*}{ Sig. } & \multicolumn{2}{|c|}{$\begin{array}{l}\text { Collinearity } \\
\text { Statistics }\end{array}$} \\
\hline \multicolumn{2}{|c|}{ Model } & $B$ & Std. Error & & & & Tolerance & $V I F$ \\
\hline$\overline{1}$ & (Constant) &, 140 &, 151 & & 928 &, 384 & & \\
\hline & $U D P S$ & ,046 & 073 & , 167 & ,630 & ,549 & 609 & 1,641 \\
\hline & $T P D P S$ & ,001 & ,001 & ,208 & ,940 & ,379 & ,875 & 1,142 \\
\hline & $K D P S$ &, 000 & 001 &,- 123 &,- 498 & ,633 & ,700 & 1,429 \\
\hline & $U D K$ & , 109 &, 040 & ,738 & 2,726 & ,029 &, 584 & 1,712 \\
\hline
\end{tabular}

Sumber: Pengolahan Data di IBM SPSS Statistics 24

Pada tabel di atas diketahui bahwa nilai VIF lebih kecil dari 5 dan nilai tolerance lebih besar dari 0,1. Dengan demikian dapat disimpulkan bahwa tidak terdapat multikolinieritas pada data tersebut.

\section{Uji Autokorelasi}

Tabel. 4 Hasil Uji Autokorelasi

\begin{tabular}{llllll}
\hline \multicolumn{4}{c}{ Model Summary $^{b}$} \\
Model & $R$ & $R$ Square & Adjusted $R$ Square & Estimate & Durbin-Watson \\
\hline 1 &, $837^{a}$ &, 700 &, 529 &, 08491 & 2,334 \\
\hline \multicolumn{4}{c}{ Sumber: Pengolahan Data di IBM SPSS Statistics 24}
\end{tabular}

Pada tabel di atas, diketahui bahwa nilai D hitung $(2,334)$ lebih besar dari DU $(1,023)$ dan lebih kecil dari 4-DU $(2,977)$. Maka dapat disimpulkan bahwa tidak terjadi autokorelasi pada data tersebut.

\section{Hasil Uji Regresi}

Tabel 5. Hasil Uji Regresi

\begin{tabular}{|c|c|c|c|c|c|c|}
\hline \multicolumn{7}{|c|}{ Coefficientsa } \\
\hline \multirow[b]{2}{*}{ Model } & & \multicolumn{2}{|c|}{ Unstandardized Coefficients } & \multirow{2}{*}{$\begin{array}{l}\text { Standardized } \\
\text { Coefficients } \\
\text { Beta } \\
\end{array}$} & \multirow[b]{2}{*}{$t$} & \multirow[b]{2}{*}{ Sig. } \\
\hline & & $B$ & Std. Error & & & \\
\hline 1 & (Constant) &, 140 &, 151 & &, 928 &, 384 \\
\hline & $U D P S$ & ,046 & 073 & , 167 & 630 & ,549 \\
\hline & TPDPS &, 001 & 001 & 208 & ,940 & ,379 \\
\hline & $K D P S$ &, 000 & 001 &,- 123 &,- 498 & 633 \\
\hline & $U D K$ & 109 & 040 & 738 & 2,726 &, 029 \\
\hline
\end{tabular}

Nilai a pada tabel di atas sebesar 0,140 memiliki arti bahwa jika variabel X, yakni Ukuran DPS, Tingkat Pendidikan DPS, Keahlian DPS dan Ukuran Dewan Komisaris dalam keadaan konstan, maka variabel Y, yakni Pengungkapan ISR akan mengalami kenaikan sebesar $12 \%$. 
Pada tabel di atas juga diketahui bahwa Ukuran DPS $\left(b_{1}\right)$ memiliki nilai konstanta sebesar 0,046, yang itu artinya apabila Ukuran DPS berubah sebesar satu satuan, maka pengungkapan ISR akan mengalami peningkatan sebesar 4,6\%. Tingkat Pendidikan DPS $\left(b_{2}\right)$ memiliki nilai konstanta sebesar 0,001 yang berarti bahwa apabila Tingkat Pendidikan DPS mengalami perubahan sebesar satu satuan, maka ISR akan mengalami peningkatan sebesar 0,1\%. Adapun nilai konstanta Keahlian Dewan Pengawas Syari'ah $\left(b_{3}\right)$ adalah 0,000. Maka berarti jika perubahan yang terjadi pada keahlian DPS adalah sebesar satu satuan, maka pengungkapan ISR akan berubah sebesar 0\%. Sedangkan nilai konstanta Ukuran Dewan Komisaris $\left(\mathrm{b}_{4}\right)$ adalah 0,104 yang berarti bahwa apabila Ukuran Dewan komisaris berubah sebesar satu satuan, maka pengungkapan ISR akan mengalami peningkatan sebesar $10,4 \%$.

\section{Hasil Uji Hipotesis}

\section{Uji t}

Tabel 6. Hasil Uji t (parsial)

\begin{tabular}{|c|c|c|c|c|c|c|}
\hline No. & & Hipotesis & $B$ & Sig. & $\alpha$ & Hasil \\
\hline 1 & $H 2$ & $\begin{array}{l}\text { Ukuran Dewan Pengawas Syariah } \\
\text { berpengaruh secara positif terhadap } \\
\text { pengungkapan Islamic Social Reporting. }\end{array}$ & 0,046 & 0,549 & 0,05 & Ditolak \\
\hline 2 & $H 3$ & $\begin{array}{l}\text { Tingkat Pendidikan Dewan Pengawas } \\
\text { Syari'ah berpengaruh secara positif } \\
\text { terhadap pengungkapan Islamic Social } \\
\text { Reporting. }\end{array}$ & 0,001 & 0,379 & 0,05 & Ditolak \\
\hline 3 & $H 4$ & $\begin{array}{l}\text { Keahlian Dewan Pengawas Syari'ah } \\
\text { berpengaruh secara positif terhadap } \\
\text { pengungkapan Islamic Social Reporting. }\end{array}$ & 0,000 & 0,633 & 0,05 & Ditolak \\
\hline 4 & $H 5$ & $\begin{array}{l}\text { Ukuran Dewan Komisaris berpengaruh } \\
\text { secara positif terhadap pengungkapan } \\
\text { Islamic Social Reporting. }\end{array}$ & 0,109 & 0,029 & 0,05 & Diterima \\
\hline
\end{tabular}
Sumber: Pengolahan Data di IBM SPSS Statistics 24

Ukuran Dewan Pengawas Syari'ah berpengaruh secara positif terhadap pengungkapan Islamic Social Report.

Hipotesis ini ditolak, yang berarti bahwa Ukuran Dewan Pengawas Syari'ah tidak berpengaruh secara signifikan terhadap pengungkapan Islamic Social Reporting (ISR). Hal ini menunjukkan bahwa penambahan jumlah anggota DPS tidak akan berakibat secara signifikan terhadap perubahan Pengungkapan ISR. Sebagaimana yang dijelaskan sebelumnya bahwa jika anggota DPS ditambah sebanyak satu orang, maka Pengungkapan ISR akan meningkat hanya sekitar 4,6\%.

Tingkat Pendidikan Dewan Pengawas Syari'ah berpengaruh secara positif terhadap pengungkapan Islamic Social Reporting. Hipotesis ini ditolak, yang artinya bahwa Tingkat Pendidikan Dewan Pengawas Syari'ah tidak memberikan kontribusi yang cukup signifikan terhadap peningkatan Pengungkapan Islamic Social Reporting (ISR). Bahkan jika tingkat pendidikan DPS dinaikkan sebesar satu satuan, kontribusi yang bisa diberikan untuk menaikkan pengungkapan Islamic Social Reporting (ISR) hanya sebesar $0,1 \%$. 
Keahlian Dewan Pengawas Syari'ah berpengaruh secara positif terhadap pengungkapan Islamic Social Reporting. Hipotesis ini juga ditolak. Dengan demikian Keahlian Dewan Pengawas Syari'ah di bidang keuangan/perbankan syari'ah dan fiqh mu'amalah tidak memiliki kontribusi apapun terhadap peningkatan pengungkapan Islamic Social Reporting (ISR). Hal ini juga ditunjukkan hasil uji regresi dimana nilai b sebesar 0,000 yang itu artinya, jika keahlian DPS dinaikkan sebesar satu satuan, perubahan pada pengungkapan ISR adalah $0 \%$.

Ukuran Dewan Komisaris berpengaruh secara positif terhadap pengungkapan Islamic Social Reporting. Hipotesis ini diterima, yang artinya bahwa Ukuran Dewan Komisaris berpengaruh positif secara signifikan terhadap pengungkapan Islamic Social Reporting (ISR). Dengan demikian, peningkatan pada Ukuran Dewan komisaris akan diikuti secara positif oleh peningkatan pengungkapan ISR. Jika ukuran Dewan Komisaris ditambah sebanyak satu satuan, maka pengungkapan ISR akan mengalami peningkatan sebanyak $10,9 \%$.

\section{Uji F}

Tabel 7. Hasil Uji F (simultan)

\begin{tabular}{|c|c|c|c|c|c|c|}
\hline \multicolumn{7}{|c|}{$A N O V A^{a}$} \\
\hline \multicolumn{2}{|c|}{ Model } & \multirow{2}{*}{$\frac{\text { Sum of Squares }}{, 118}$} & \multirow{2}{*}{$\frac{d f}{4}$} & \multirow{2}{*}{$\frac{\text { Mean Square }}{, 029}$} & $F$ & Sig. \\
\hline$\overline{1}$ & Regression & & & & 4,088 &, $050^{b}$ \\
\hline & Residual &, 050 & 7 &, 007 & & \\
\hline & Total &, 168 & 11 & & & \\
\hline
\end{tabular}

Sumber: Pengolahan Data di IBM SPSS Statistics 24

Dari tabel di atas dapat diketahui bahwa nilai signifikansinya adalah sebesar 0,05 dan karena itu hipotesis diterima. Hal ini juga diperkuat dengan nilai $\mathrm{F}$ yang lebih besar dari 1,96, yakni 4,088. Dengan demikian dapat disimpulkan bahwa Ukuran Dewan Pengawas Syari'ah, Tingkat Pendidikan Dewan Pengawas Syari'ah, Keahlian Dewan Pengawas Syari'ah dan Ukuran Dewan komisaris berpengaruh secara signifikan dan positif terhadap pengungkapan Islamic Social Reporting (ISR).

\section{Uji Koefisien Determinasi}

Tabel 10. Hasil Uji Koefisien Determinasi

\begin{tabular}{|c|c|c|c|c|}
\hline \multicolumn{5}{|c|}{ Model Summary } \\
\hline Model & $R$ & $R$ Square & Adjusted $R$ Square & $\begin{array}{l}\text { Std. Error of the } \\
\text { Estimate }\end{array}$ \\
\hline 1 &, $837^{a}$ &, 700 &, 529 & ,08491 \\
\hline
\end{tabular}

Dapat diketahui dari tabel di atas bahwa nilai $\mathrm{R}$ Square adalah 0,700. Hal ini berarti bahwa kemampuan variabel $\mathrm{X}$ untuk mempengaruhi variabel $\mathrm{Y}$ adalah sebesar $70 \%$. Sementara sisanya sebesar $30 \%$ dipengaruhi oleh faktor lain yang tidak diteliti. 


\section{KESIMPULAN}

Dewan Pengawas Syari'ah adalah suatu badan yang bertugas mengawasi pelaksanaan fatwa DSN di lembaga keuangan syari'ah. Karakteristik Dewan Pengawas Syari'ah dalam penelitian ini mencakup tiga hal, yaitu ukuran, tingkat pendidikan dan keahlian Dewan Pengawas Syari'ah.

Ukuran Dewan Komisaris merupakan jumlah anggota Dewan Komisaris dalam suatu perusahaan, yang dinilai/diketahui dengan cara menghitung jumlah dewan komisaris yang tercantum dalam laporan tahunan perusahaan. Islamic Social Reporting (ISR) adalah suatu standar pelaporan berbasis syariah yang bertujuan untuk melihat kinerja dan tanggung jawab sosial perusahaan.

Pada uji t yang dilakukan, semua variabel $\mathrm{X}$ tidak berpengaruh signifikan terhadap variabel Y, kecuali Ukuran Dewan komisaris yang memberikan kontribusi sebesar 10,9\% terhadap pengungkapan ISR. Sedangkan pada uji F, variabel $\mathrm{X}$ berpengaruh secara signifikan terhadap variabel Y dengan koefisien determinasi sebesar 0,700.

\section{REFERENSI}

Agustomi. (2019). Pengaruh Ukuran Perusahaan, Ukuran Dewan Komisaris, Ukuran Dewan Pengawas Syari'ah, Cross-Directorship dan Liputan Media terhadap Pengungkapan Islamic Social Reporting (ISR) Bank Umum Syariah Priode 20162018 .[Skripsi]. Universitas Islam Negeri Raden Intan.

Ahzar, F. A. (2013). Pengungkapan Islamic Social Reporting Pada Bank Syariah Di Indonesia. [S1, Universitas Muhammadiyah Surakarta]. http://eprints.ums.ac.id/23093/

Astuti, T. (t.t.). Pengaruh Profitabilitas, Likuiditas dan Leverage Terhadap Pengungkapan Islamic Social Reporting (Studi Empiris pada Perusahaan yang Terdaftar di JII Tahun 2010-2012). 20.

Busyra Azheri. (2011). Corporate Social Responsibility: Dari Voluntary Menjadi Mandatory. PT RajaGrafindo Persada.

Eksandy, A. (2018). Pengaruh Good Corporate Governance terhadap Kinerja Keuangan pada Perbankan Syari'ah Indonesia. JAK (Jurnal Akuntansi): Kajian Ilmiah Akuntansi, 5(1), 1-10. https://doi.org/10.30656/jak.v5i1.498

Fauziah, K., \& J, P. Y. (2013). Analisis Pengungkapan Tanggung Jawab Sosial Perbankan Syariah di Indonesia Berdasarkan Islamic Social Reporting Indeks. Jurnal Dinamika Akuntansi, 5(1), Article 1. https://doi.org/10.15294/jda.v5i1.2559

Fitria, S., \& Hartanti, D. (2010). Islam dan Tanggung Jawab Sosial: Studi Perbandingan Pengungkapan Berdasarkan Global Reporting Initiative Indeks dan Islamic Social Reporting Indeks. Simponsium Nasional Akuntansi XIII, 46.

Fitriana, R., Yulianto, A., \& Solikhah, B. (2019). Are Characteristics Of Sharia Supervisory Boards Able To Improve The Performance Of Islamic Banking? Journal Of Islamic Accounting And Finance Research. 1(1), 1. https://doi.org/10.21580/jiafr.2019.1.1.3753 
Pengaruh Karakteristik Dewan Pengawas Syari'ah dan Ukuran Dewan Komisaris terhadap Pengungkapan Islamic Social Reporting

Khasanah, Z., \& Yulianto, A. (2015). Islamic Corporate Governance dan Pengungkapan Islamic Social Reporting pada Bank Umum Syariah. Accounting Analysis Journal, 4(4), Article 4. https://doi.org/10.15294/aaj.v4i4.9108

Khoirudin, A. (2013). Corporate Governance dan Pengungkapan Islamic Social Reporting pada Perbankan Syariah di Indonesia. Accounting Analysis Journal, 2(2), Article 2. https://doi.org/10.15294/aaj.v2i2.2919

Marharani, A. K., \& Yulianto, A. (2016). Faktor-Faktor yang Mempengaruhi Tingkat Pengungkapan Islamic Social Reporting pada Bank Syariah. Accounting Analysis Journal, 5(1), Article 1. https://doi.org/10.15294/aaj.v5i1.9746

Muti'ah Khoirunnisa. (2019). Pengaruh Zakat Perusahaan dan Karakteristik Dewan Pengawas Syariah (DPS) terhadap Kinerja Perbankan Syariah di Malaysia. Jurusan Akuntansi Syariah, Fakultas Ekonomi dan Bisnis Islam, Institut Agama Islam Negeri Surakarta.

Othman, R., \& Thani, A. M. (2010). Islamic Social Reporting Of Listed Companies In Malaysia. International Business \& Economics Research Journal (IBER), 9(4), Article 4. https://doi.org/10.19030/iber.v9i4.561

Ramadhani, F., Desmiyawati, D., \& Kurnia, P. (2016). Pengaruh Ukuran Perusahaan, Profitabilitas, Leverage Dan Ukuran Dewan Pengawas Syariah Terhadap Pengungkapan Islamic Social Reporting (Studi Empiris Pada Bank Umum Syariah Di Indonesia Tahun 2010-2014). (Nomor 1) [Journal:eArticle, Riau University]. https://www.neliti.comNone

Sofyani, H., Ulum, I., Syam, D., \& L, S. W. (2012). Islamic Social Reporting Index Sebagai Model Pengukuran Kinerja Sosial Perbankan Syariah (Studi Komparasi Indonesia dan Malaysia). Jurnal Dinamika Akuntansi, 4(1), Article 1. https://doi.org/10.15294/jda.v4i1.1958

Sunarsih, U., \& Ferdiansyah, F. (2016). Determinants of The Islamic Social Reporting Disclosure. Al-Iqtishad: Jurnal Ilmu Ekonomi Syariah. 9(1), 69-80-80. https://doi.org/10.15408/aiq.v9i1.3771 